\title{
A Clinical Study on Sleshmala Yonivyapad through Anubhoota Yoga the 'Patrangadi Yoga'
}

\author{
Shweta Sindagi', Savita Sajjan ${ }^{2}$, Anita Halagatti ${ }^{3}$ \\ ${ }^{1}$ PG Scholar, Department of Moulika Siddhanta, Ayurveda Mahavidyalaya Hubli \\ ${ }^{2}$ Professor in Department of Moulika Siddhanta, Ayurveda Mahavidyalaya Hubli \\ ${ }^{3}$ Associate Professor, Department of Prasooti and Streeroga, Ayurveda Mahavidyalaya \\ Corresponding Author: Shweta Sindagi
}

\begin{abstract}
Sleshmala yonivyapad is one of the most common and burning problem faced by the women all around the globe. The symptoms are vaginal white discharge, itching, foul smell mild pain in vagina. On the bases of chief complaints and review of the disease the shlesmala yonivyapat is compared with Trichomonas vaginalis.

There are many treatments prescribed for this problem but they are not free from side effects and with reoccurrence. Hence selection of an appropriate treatment is very essential.

Study design: In the present study, 30 patients fulfilling criteria of sleshmala yonivyapat were selected under single group. Patients were given Patrangadi churna 4gms thrice a day with ushnodaka internally after food for 7 days and Yoniprakshalana with Patrangadi kashaya for 7 days.

This study was carried out for 21 days. The signs and symptoms were observed before and after treatment and were compared.

Subjective parameters: Picchila shweta srava, Dourgandya, Kandu and Alpavedana.

Objective parameters: Profuse thick creamy discharge, Red and swollen vulva with evidence of pruritus like scratch marks and wet mount showing Trichomonas vaginalis positive.

Result: In the present study total 11 subjects showed complete relief, 17 subjects showed moderate relief and 2 subjects showed partial relief after treatment.

And 11 subjects showed complete relief, 7 subjects showed moderate relief, 7 subjects showed partial relief and 5 subjects showed no relief after follow up.

The total effect of therapy provided statistically highly significant result $(p<0.001)$ in both subjective and objective parameters.

Paired ' $t$ ' test is applied. Thus the study showed the effectiveness of Patrangadi churna internally as well as Patrangadi kashaya yoniprakshalana in alleviating symptoms of sleshmala yonivyapad.
\end{abstract}

Key words: Sleshmala yonivyapad, Patrangadi yoga, Trichomonas vaginalis.

\section{INTRODUCTION}

Yoni being a direct route to Garbhashaya if diseased, might affect the entire kshetra which is needed for growing embryo and its development. Ayurveda explains 20 different conditions related to this yoni called as yonivyapat ${ }^{1}$. These 20 yonivyapat include most of the abnormal and diseased conditions of vagina. Sleshmala yonivyapad is one among most frequently seen condition in these yonivyapad. Shleshmala Yoni Vyapad is one among twenty yonivyapad. It has been described by Acharya Charaka and both Vagbhata as Shlaishmiki. Acharya Sushruta, Bhavaprakasha and Yogaratnakara have used the term Sleshmala ${ }^{2}$ yonivyapad whereas Sharangadhara has just mentioned Kaphaja. Sleshmala word refers to Sleshmayukta. The word Sleshma refers to Kapha dosha ie Slisha Alingane. 
Table No 1: CLASSIFICATION OF SLESHMALA YONIVYAPAT:

\begin{tabular}{|l|c|c|c|c|c|c|}
\hline Disease & Charaka & Sushruta & Vagbhata & Madhava Nidana & Bhavaprakasha & Yogaratnakara \\
\hline Sleshmiki & + & - & + & - & - & - \\
\hline Atyananda & - & + & - & + & + & + \\
\hline Karnini & - & + & - & + & + & + \\
\hline Acharana & - & + & - & - & - & - \\
\hline Aticharana & - & + & - & + & + & + \\
\hline Sleshmala & - & + & - & + & + & + \\
\hline Anandacharana & - & - & - & + & + & + \\
\hline
\end{tabular}

\section{Nidana:}

Specific etiologies mentioned are, Abhishyandi Ahara ${ }^{3}$

Kapha prakopaka ahara

Abhishyanda Ahara is defined as Ahara which increases Srava

Those products that have picchila guna, and Guru guna able to vitiate the Rasavaha Strotas and cause avarodha, leading to Gouravam are called Abhishyandi Dravyas. Eg, curd. As they have Guna Sadharmyata with Sleshma, it causes Sleshma Prakopa.

Doshadhatumalasrotasaamatishayakl edapraptijanakam ${ }^{4}$.

Vata prakopaka ahara also plays important role in manifestation of disease.

\section{Vata prakopaka ahara:}

Katu, tikta, ruksha, laghu ahara, sheeta virya, Sushka shaka, Valluraka,Uddalaka, Koradushaka, Shyamaka, Nivara, Mudga, Masoora, Aadaki, Harenuka, Kalaya, Nishpava

\section{Vataprakopaka Vihara ${ }^{5}$ :}

Ativyayam, Prajagarana (night awakening), Langhana, Plavana, Atiadhva, vyayama, Krodha, Vegadharana, Dhukha shayyasana, Rogatikarshana, Abhighata, Marmabhighata, Gajoshtrashva shigrayana apatamsanat, Atisamshadhana

\section{Kapha Prakopaka Ahara:}

Hayanaka, Yavaka, Naishada, Masha, Mahamasha, Godhuma,Tilapishta vikruti, Dadhi, Dugdha, Krushara, Payasa, Ikshuvikara, Anupamamsa, Vasa, Visamrunala, Kaseruka, Shrungataka, Madhuravalliphala

\section{Kaphaprakopaka Vihara:}

Divaswapna, Avyayama, Aalasya, Samashana, Adyashana.

Table No 2: Lakshanas of Sleshmala Yonivyapad according to different Acharyas

\begin{tabular}{|l|l|l|l|}
\hline Lakshanas & Charaka $^{6}$ & Sushruta $^{7}$ & Vagbhata $^{8}$ \\
\hline Sleshmala & - & + & - \\
\hline Picchila & + & + & + \\
\hline Kandu & + & + & + \\
\hline Sheeta & + & + & + \\
\hline Alpavedana & + & - & - \\
\hline Avedana & - & - & + \\
\hline Pandutvam & + & - & - \\
\hline
\end{tabular}

Chakrapani equated this with Kaphaja asrigdhara on the basis that yellowish discharge per vagina is present during intermenstrual period also ${ }^{9}$.

Acharya Sushrutha has given only local symptoms as presence of Picchila, kandu and Atisheetala

Acharya Vagbhata has given the lakshanas as picchila, sheeta, kandu and Avedana

Madhava Nidana, Bhavaprakasha and Yogaratnakara have explained same as that of Sushrutha.

Madhukosha vyakhyakara has considered presence of vedana ${ }^{10}$.

\section{Samprapti:}

Sanchaya Avasta (stage of accumulation:

In all yonivyapad, all these changes take place before the occurrence of the particular disease. Acharya Sushruta has very clearly mentioned that a man with abnormal genitalia when indulges into coitus with a very young girl or woman in an undesired and un-comfortable position then the vata becomes vitiated and this vitiated vata starts getting sanchaya in the garbhashaya with the help of other two doshas- pitta and kapha to produce yonivyapad. 
Regarding the Yonivyapad, it has been narrated clearly that kapha wil not vitiate without the involvement of vata dosha. The practice of vata provoking factors like ruksha, laghu, sheeta etc food vitiates vata and makes jataragnimandya eventually formed ama commence to accumulated (sanchaya) in the amashaya.

\section{Prakopa Avasta:}

After the accumulation of more and more of this kind of ama, in its ashaya, the unmargagamana of it occurs with specific prakopaka factors in the prakopavasta. During this stage, patient complaints of annadvesha, angamarda, alasya etc.

Prasara Avasta:The dushta ama then circulates all over the body through rasavaha srotas by the vyana vayu in the prasava avasta. Circulating ama causes excessive vata aggravation and rasavaha srotas dushti.

\section{Sthanasamshraya Avasta:}

Due to unwholesome ahara and vihara, over indulgence in sexual activities etc the vitiated vata dwelling at trayavartyoni (Stanasamshraya) and produces the khavaigunya in the artavavaha srotas. Due to agni vaishamya and srotas avarodha, kapha dosha and rasa dhatu are formed excessively in yonipradesha.

Vyakta Avasta: In this avasta there is appearance of white discharge through vagina by the activity of expulsion of apana $v a y u$, as the appearance of symptoms like yonisrava, picchilata, kandu etc.

\section{Bheda Avasta:}

The dirghakalika anubandhatva ie chronic nature of this ailment can be considered as the sixth avastha of kriyakala ie Bhedavasta. In this disease process mainly the sthanika kapha and rasa dhatu plays a very important role whereas vata dosha takes as initiative for it.

\begin{tabular}{|l|l|}
\hline \multicolumn{1}{|c|}{ Table no 3 : SAMPRAPTI GHATAKAS } \\
\hline & $\begin{array}{l}\text { Kapha and vata pradhana dosha } \\
\text { Vata- Apana vata } \\
\text { Pitta-Pachaka pitta } \\
\text { Kapha- Kledaka kapha }\end{array}$ \\
\hline Dushya & $\begin{array}{l}\text { Dhatu-Rasa, Rakta,mamsa } \\
\text { Upadhatu-Artava }\end{array}$ \\
\hline Agni & $\begin{array}{l}\text { Jataragnimandya } \\
\text { Rasadhatwagnimandya }\end{array}$ \\
\hline Ama & Saama \\
\hline Srotas & Rasavaha, Raktavaha and Artavavaha \\
\hline $\begin{array}{l}\text { Srotaodushti } \\
\text { prakara }\end{array}$ & Atipravrutti \\
\hline Udbhava sthana & Pakvashaya \\
\hline Sanchara sthana & Rasavaha srotas and Garbhashaya \\
\hline Vyakta sthana & Yoni and Garbhashaya \\
\hline Adhistana & Yoni \\
\hline Rogamarga & Abhyantara \\
\hline
\end{tabular}

\section{AIMS AND OBJECTIVES}

A Clinical study on Sleshmala yonivyapad and its chikitsa Siddhanta.

To evaluate the efficacy of Patrangadi yoga (Anubhoota yoga) in Sleshmalayonivyapad

\section{MATERIALS AND METHODS}

The following materials were utilized for clinical trial:

Patrangadiyoga consists of 10 drugs, they are,

$\begin{array}{lll}\text { Patranga } & - & 2 \text { parts } \\ \text { Chopachini } & - & 2 \text { parts } \\ \text { Daruharidra } & - & 2 \text { parts } \\ \text { Kutaja } & - & 2 \text { partss } \\ \text { Chirabilva } & - & 2 \text { parts } \\ \text { Nimba } & - & 1 \text { part } \\ \text { Musta } & - & 1 \text { part } \\ \text { Lodhra } & - & 1 \text { part } \\ \text { Ashoka - } & & 1 \text { part } \\ \text { Jatiphala } & - & 1 / 2 \text { parts }\end{array}$

\section{Diagnotic criteria:}

Diagnosis is based on the classical symptoms of Sleshmala yonivyapad.

\section{Inclusion criteria:}

Married woman fulfilling the diagnostic criteria of Sleshmala yonivyapad.

Chronic sleshmala yonivyapad (>1 year)

\section{Exclusion criteria:}

Unmarried woman

Post Menopausal

Cevical Erosion

Pregnancy and lactation 
STD

Contraceptive measures and barrier methods.

\section{Examination of the patients:}

In this study the data was collected from the patients with the help of interview. The detailed data related to general history, history of past illness, present illness, family history, food habits, history of treatment taken so far etc, were recorded in the
Performa of the case sheet. The systemic examinations of the patient were also done and findings were recorded as per the Proforma. Stanika pariksha which includes per vaginal and per speculum examination was carried out.

Instruments like Sims speculum, Anterior vaginal wall retractor, Sponge holding forceps, Torch, Sterile cotton were used. Gynecological examination was done.

Table No 4: GRADES FOR ASSESMENT OF SUBJECTIVE PARAMETERS

\begin{tabular}{|l|l|}
\hline SUBJECTIVE PARAMETER & SYMPTOM SCORE \\
\hline KANDU & \\
\hline Absent & 0 \\
\hline Mild(without the need of scratching) & 1 \\
\hline Moderate(relief by scratching, without excoriations) & 2 \\
\hline Severe(unrelieved by scratching, restlessness, excoriations) & 3 \\
\hline YONI VEDANA & \\
\hline Absent & 0 \\
\hline Mild(Localised feeling of pain during movement only but no pain during rest) & 1 \\
\hline Moderate(Localised feeling of pain even during rest but not disturbing the sleep) & 2 \\
\hline Severe(Localised continuous feeling of pain, radiating and disturbing sleep) & 3 \\
\hline \multicolumn{1}{|c|}{ DOURGANDYA } & \\
\hline Absent & 0 \\
\hline Present & 1 \\
\hline YONISRAVA & \\
\hline Absent & 0 \\
\hline Mild(Occasional slight discharge(only vulval moistness) & 1 \\
\hline Moderate(needs to change undergarment twice a day) & 2 \\
\hline Severe(needs to use pad/frequent change of undergarment) & 3 \\
\hline
\end{tabular}

Table No 5: GRADE FOR ASSESMENT OF OBJECTIVE PARAMETERS

\begin{tabular}{|l|l|}
\hline OBJECTIVE PARAMETERS & $\begin{array}{l}\text { SYMPTOM } \\
\text { SCORE }\end{array}$ \\
\hline External genital appearance & \\
\hline Healthy and normal & 0 \\
\hline Reddish with mild scratch marks on vulva & 1 \\
\hline Reddish, & 2 \\
\hline $\begin{array}{l}\text { Reddish, scratch marks until to bleed, } \\
\text { soreness of vulva }\end{array}$ & 3 \\
\hline Discharge Quantity & \\
\hline Not significant & 0 \\
\hline $\begin{array}{l}\text { Discharge seen but does not get collected in } \\
\text { speculum }\end{array}$ & 1 \\
\hline $\begin{array}{l}\text { Scanty discharge collected in posterior blade } \\
\text { of speculum }\end{array}$ & 2 \\
\hline $\begin{array}{l}\text { Profuse discharge collected in posterior } \\
\text { blade of speculum }\end{array}$ & 3 \\
\hline $\begin{array}{l}\text { Wet mount showing Trichomonas vaginalis } \\
\text { positive }\end{array}$ & \\
\hline Organism Present & 0 \\
\hline Organism Absent & 1 \\
\hline
\end{tabular}

\section{Study design:}

This is a literary and clinical study Sample size:

A minimum of 30 subjects of Sleshmala yonivyapad will be selected and will be studied under single group

\section{Assessment criteria:}

The data, which are obtained by clinical trial will be statistically analyzed by applying Student paired 't' test.

\begin{tabular}{|l|l|}
\multicolumn{2}{|c}{ Table No 6: Overall effect of therapy } \\
\hline No change & $0 \%-25 \%$ relief of signs and symptoms \\
\hline Mild improvement & $26 \%-50 \%$ relief of signs and symptoms \\
\hline Moderate improvement & $51 \%-75 \%$ relief of signs and symptoms \\
\hline Marked improvement & $51 \%-75 \%$ relief of symptoms \\
\hline Complete Remission & $76 \%-100 \%$ relief of symptoms \\
\hline
\end{tabular}

\section{RESULT \\ EFFECT ON SUBJECTIVE CRITERIA}

Table No 7: Effect on treatment on Picchila shweta srava

\begin{tabular}{|l|l|l|l|l|l|l|l|l|}
\hline Mean of BT & Mean & Mean & \multicolumn{4}{|l|}{ Percentage of improvements (Mean difference) } & \multicolumn{3}{|l|}{ Paired t Test } \\
\cline { 4 - 9 } & & & & SD & SE & t & P \\
\hline 0.97 & AT & 0.70 & 1.33 & $65.52 \%$ & 0.48 & 0.09 & 15.23 & $<0.001$ \\
\hline & AF & 1.07 & 0.97 & $47.78 \%$ & 0.76 & 0.14 & 6.92 & $<0.001$ \\
\hline
\end{tabular}


The mean score of the symptom which was 2.03 before treatment, reduced to 0.70 after treatment and reduced to 1.07 in the follow up. By evaluating above table among 30 patients, highly significant result was found in Yonisrava after treatment and during follow up $(\mathrm{p}<0.001)$.

\begin{tabular}{|c|c|c|c|c|c|c|c|c|}
\hline \multirow[t]{2}{*}{ Mean of BT } & \multirow[t]{2}{*}{ Mean } & \multirow[t]{2}{*}{ Mean } & \multicolumn{2}{|c|}{ Percentage of improvements (Mean difference) } & \multicolumn{4}{|c|}{ Paired t Test } \\
\hline & & & & & SD & SE & $\mathbf{t}$ & $\mathbf{P}$ \\
\hline 0.6 & AT & 0.00 & 0.60 & $100 \%$ & 0.49 & 0.09 & 6.59 & $<0.001$ \\
\hline 0.6 & $\mathrm{AF}$ & 0.00 & 0.60 & $100 \%$ & 0.49 & 0.09 & 6.59 & $<0.001$ \\
\hline
\end{tabular}

The mean score of the symptom which was 0.6 before treatment, reduced to 0.00 after treatment as well as on follow up. By evaluating the above table among 30 patients, highly significant result was found in Dourgandya after treatment and during follow up $(\mathrm{p}<0.001)$

Table No 9: Effect of treatment on Yonikandu

\begin{tabular}{|l|l|l|l|l|l|l|l|l|}
\hline Mean of BT & Mean & Mean & \multicolumn{4}{|l|}{ Percentage of improvements (Mean difference) } & \multicolumn{4}{|l|}{ Paired t Test } \\
\cline { 5 - 9 } & & & & SD & SE & t & P \\
\hline 1.7 & AT & 0.67 & 1.03 & $60.59 \%$ & 0.18 & 0.03 & 31.00 & $<0.001$ \\
\hline & AF & 0.93 & 0.77 & $45.29 \%$ & 0.57 & 0.10 & 7.39 & $<0.001$ \\
\hline
\end{tabular}

The mean score of the symptom which was 1.7 before treatment, reduced to 0.67 after treatment and increased to 0.93 in first and second follow up. By evaluating above table among 30 patients, highly significant result was found in Yonikandu after treatment and during follow up $(\mathrm{p}<0.001)$

Table No 10: Effect on treatment on Alpavedana

\begin{tabular}{|l|l|l|l|l|l|l|l|l|}
\hline Mean of BT & Mean & Mean & \multicolumn{3}{|l|}{ Percentage of improvements (Mean difference) } & \multicolumn{3}{|l|}{ Paired t Test } \\
\cline { 4 - 9 } & & & & SD & SE & t & P \\
\hline 0.97 & AT & 0.30 & 0.67 & $60.07 \%$ & 1.15 & 0.21 & 3.16 & $<0.001$ \\
\hline & AF & 0.17 & 0.80 & $82.47 \%$ & 0.55 & 0.10 & 7.95 & $<0.001$ \\
\hline
\end{tabular}

The mean score of the symptoms which was 0.97 before treatment, reduced to 0.30 after treatment, reduced to 0.17 in follow up. By evaluating above table among
30 patients highly significant result was found in yonivedana after treatment and during follow up $(\mathrm{p}<0.001)$

Table No 11: Effect of treatment on profuse thick creamy discharge

\begin{tabular}{|l|l|l|l|l|l|l|l|l|}
\hline Mean of BT & Mean & Mean & \multicolumn{3}{|l|}{ Percentage of improvements (Mean difference) } & \multicolumn{3}{|l|}{ Paired t Test } \\
\cline { 3 - 9 } & & & & SD & SE & t & P \\
\hline 1.90 & AT & 0.70 & 1.20 & $63.16 \%$ & 0.55 & 0.10 & 11.93 & $<0.001$ \\
\hline & AF & 1.07 & 0.83 & $43.68 \%$ & 0.79 & 0.14 & 5.77 & $<0.001$ \\
\hline
\end{tabular}

The mean score of the symptom which was 1.9 before treatment, reduced to 0.70 after treatment and increased to 1.07 during follow up. By evaluating above table among 30 patients, highly significant result was found in Discharge quantity after treatment and during follow up $(\mathrm{p}<0.001)$

\begin{tabular}{|c|c|c|c|c|c|c|c|c|}
\hline \multirow{3}{*}{\begin{tabular}{|l|} 
Mean of BT \\
1.43 \\
\end{tabular}} & \multirow{3}{*}{$\begin{array}{l}\text { Mean } \\
\text { AT } \\
\end{array}$} & \multirow{3}{*}{$\begin{array}{l}\text { Mean } \\
0.63 \\
\end{array}$} & \multirow{2}{*}{\multicolumn{2}{|c|}{ Percentage of improvements (Mean difference) }} & \multicolumn{4}{|c|}{ Paired t Test } \\
\hline & & & & & SD & SE & $t$ & $\mathbf{P}$ \\
\hline & & & 0.80 & $55.94 \%$ & 0.41 & 0.07 & 10.77 & $<0.001$ \\
\hline & $\mathrm{AF}$ & 0.73 & 0.70 & $48.95 \%$ & 0.47 & 0.09 & 8.23 & $<0.001$ \\
\hline
\end{tabular}

The mean score of the symptom which was 1.43 before treatment, reduced to 0.63 after treatment and increased to 0.73 in follow up. By evaluating above table among
30 patients, highly significant result was found in External genital appearance after treatment and during follow up $(\mathrm{p}<0.001)$. 
Shweta Sindagi et.al. A clinical study on sleshmala yonivyapad through anubhoota yoga the 'patrangadi yoga'.

Table No 13: WET MOUNT SHOWING TRICHOMONAS VAGINALIS POSITIVE

\begin{tabular}{|l|l|l|l|l|l|l|l|}
\hline & MEAN & MD & \% RELIEF & SD & SE & 't' & P value \\
\hline BT & 1 & & & & & & \\
\hline AT & 0.2 & 0.8 & $79.38 \%$ & 0.5 & 0.09 & 8.33 & $\mathrm{P}<0.001$ \\
\hline AF & 0.2 & 0.8 & $79.38 \%$ & 0.5 & 0.09 & 8.33 & $\mathrm{P}<0.001$ \\
\hline
\end{tabular}

\begin{tabular}{|c|c|c|c|c|c|c|c|c|}
\hline $\begin{array}{l}S L . \\
N O\end{array}$ & $\begin{array}{l}\text { ASSESSMENT } \\
\text { PARAMETERS }\end{array}$ & $\begin{array}{l}\text { MEAN } \\
(B T)\end{array}$ & $\begin{array}{l}\text { MEAN } \\
(A T)\end{array}$ & $\begin{array}{l}\text { MEAN } \\
(A F)\end{array}$ & $\begin{array}{l}\text { OVERALL } \\
\text { RELIEF IN \% } \\
(A T)\end{array}$ & REMARKS & $\begin{array}{l}\text { OVERALL } \\
\text { RELIEF IN \% } \\
(A F)\end{array}$ & REMARKS \\
\hline 1 & Picchila shweta srava & 2.03 & 0.70 & 1.07 & 65.52 & $\begin{array}{l}\text { Moderate } \\
\text { relief }\end{array}$ & 47.78 & $\begin{array}{l}\text { Partial } \\
\text { relief }\end{array}$ \\
\hline 2 & Dourgandya & 0.6 & 0.00 & 0.00 & 100 & $\begin{array}{l}\text { Complete } \\
\text { relief }\end{array}$ & 100 & $\begin{array}{l}\text { Complete } \\
\text { relief }\end{array}$ \\
\hline 3 & Kandu & 1.7 & 0.67 & 0.93 & 60.59 & $\begin{array}{l}\text { Moderate } \\
\text { relief }\end{array}$ & 45.29 & $\begin{array}{l}\text { Partial } \\
\text { relief }\end{array}$ \\
\hline 4 & Alpavedana & 0.97 & 0.30 & 0.17 & 68.04 & $\begin{array}{l}\text { Moderate } \\
\text { relief }\end{array}$ & 82.47 & $\begin{array}{l}\text { Complete } \\
\text { relief }\end{array}$ \\
\hline 5 & $\begin{array}{lll}\begin{array}{l}\text { Profuse } \\
\text { discharge }\end{array} & \text { thick } & \text { creamy } \\
\end{array}$ & 1.9 & 0.70 & 1.07 & 63.16 & $\begin{array}{l}\text { Moderate } \\
\text { relief }\end{array}$ & 43.68 & $\begin{array}{l}\text { Partial } \\
\text { relief }\end{array}$ \\
\hline 6 & $\begin{array}{l}\text { Red and swollen vulva with } \\
\text { evidence of pruritis like } \\
\text { scratch marks }\end{array}$ & 1.43 & 0.63 & 0.73 & 55.94 & $\begin{array}{l}\text { Moderate } \\
\text { relief }\end{array}$ & 48.95 & $\begin{array}{l}\text { Partial } \\
\text { relief }\end{array}$ \\
\hline 7 & $\begin{array}{lc}\begin{array}{l}\text { Wet mount } \\
\text { Trichomonas }\end{array} & \text { showing } \\
\text { positive } & \text { vaginalis } \\
\end{array}$ & 1 & 0.2 & 0.2 & 79.38 & $\begin{array}{l}\text { Complete } \\
\text { relief }\end{array}$ & 79.37 & $\begin{array}{l}\text { Complete } \\
\text { relief }\end{array}$ \\
\hline
\end{tabular}

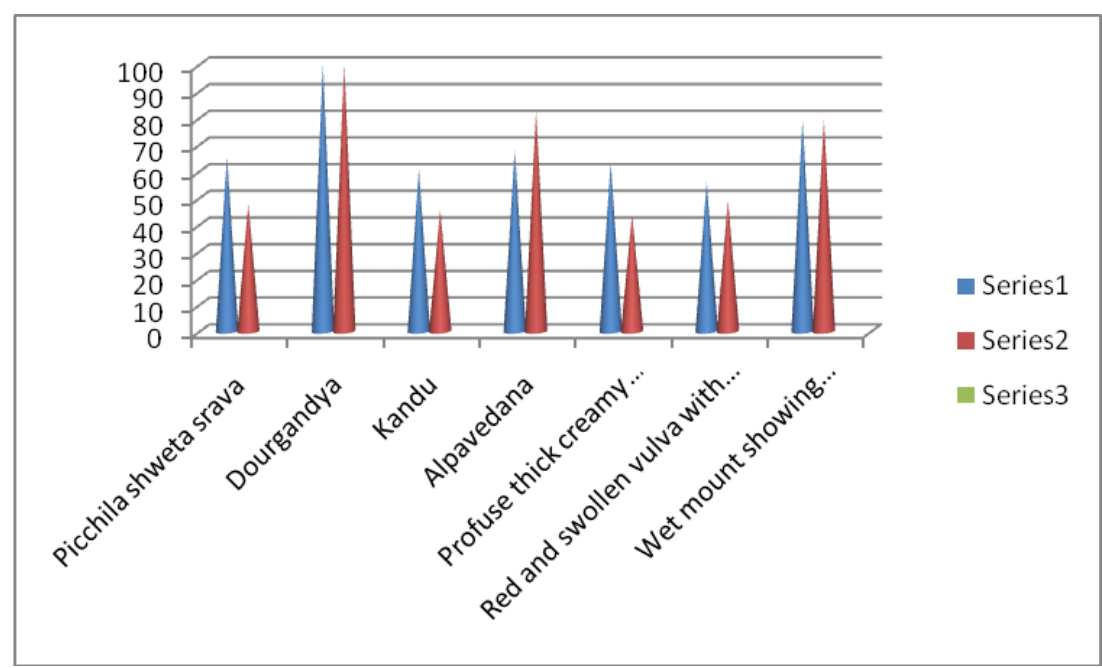

\section{Graph No 1: OVERALL RESULT ON EACH PARAMETER OF THE STUDY}

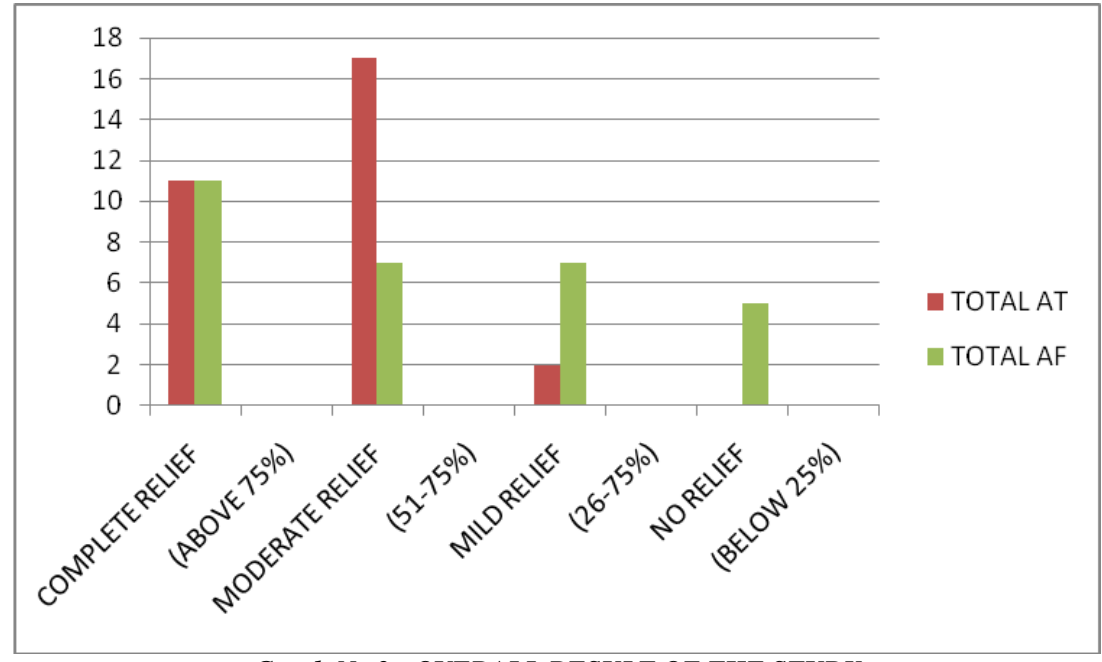

Graph No 2 : OVERALL RESULT OF THE STUDY 
Table No 15: OVERALL RESULT OF STUDY

\begin{tabular}{|l|l|l|}
\hline$\%$ RELIEF & $\begin{array}{l}\text { TOTAL NUMBER OF TOTAL NUMBER } \\
\text { PATIENTS AFTER } \\
\text { TREATMENT (A.T) }\end{array}$ & $\begin{array}{l}\text { OF PATIENTS } \\
\text { AFTER FOLLOW- } \\
\text { UP (A.F) }\end{array}$ \\
\hline $\begin{array}{l}\text { Complete } \\
\text { Relief(Above } \\
76 \%)\end{array}$ & 11 & 11 \\
\hline $\begin{array}{l}\text { Moderate } \\
\text { Relief(51- } \\
75 \%)\end{array}$ & 17 & 7 \\
\hline $\begin{array}{l}\text { Mild Relief } \\
\text { (26-50\%) }\end{array}$ & 2 & 7 \\
\hline $\begin{array}{l}\text { No Relief } \\
\text { (Below 25\%) }\end{array}$ & 0 & 5 \\
\hline
\end{tabular}

\section{DISCUSSION}

Probable role of patrangadi yoga in samprapti vighatana of sleshmala yonivyapad.

Acharya charaka has mentioned that, all drugs carry out their actions due to their five properties viz. rasa, guna, virya, vipaka and prabhava called as rasa panchakas. Let us consider the rasa panchakas of patrangadi yoga on the bases of fundamental principles of ayurveda as follows.

Rasa panchaka of patrangadi yoga:

Rasa: tikta pradhana kashaya and katu rasa

Guna: laghu, ruksha, ushna and teekshna

Veerya: ushna

Vipaka: katu

Prabhava: yoni shodhaka

Karma: Deepana, paachana,shodhana, ropana, ushna grahi(shoshana)

Doshagna karma: kapha vataghna

Probable mode of action of patrangadi yoga on the bases of dravya guna panchaka.

Tikta rasa: Akash mahabhoota predominates in tikta rasa and it acts as krimighna, kandughna, lekhana, kleda puya pitta sleshma upashoshana, sthirikarana of mamsa and twak, sukshma guna pradhana; so it removes the damaged epithelial cells, pus, inflammatory secretion like exudates, bacteria etc.

Kashaya rasa: Kashaya rasa dominating the vayu and prithvi mahabhoota, it does have samshamana, sangrahi, sandhanakara, ropana, soshana, sthambana, sleshmapittaprashamana, kleda upashoshana properties.

Katu rasa: Majority of drugs of this formulation have katu rasa which is dominated by vayu and agni mahabhuta. It acts as kledashoshaka, kandu nashaka, krimi nashaka, scraping of dushita mamsa, dilatation of srotas.

Laghu: Laghu guna is predominant of agni and akasha mahabhoota. It acts as kapha shamana, mala kshaya.

Ruksha: Ruksha guna is predominant of vayu mahabhoota, it does the shoshana of increased jala mahabhoota and kapha shamana.

Ushna: It does pachana, vilayana, vatakapha shaman, it pacifies vata dominance.

Teekshna: Tikshna guna is agni and vayu mahabhoota pradhana.

Samprapti vighatana- an insight into dravya karmukata:

Dosha: Kapha being pradhana dosha in shleshmala yonivyapat,it gets mitigated by katu, tikta kashaya rasa and laghu, ruksa, ushna and teekshna gunas; Ushna veerya of yoga helps in mitigating vata dosha.

Dushya: Laghu \& ruksha guna of patrangadi yoga helps in srotoshodhana and helps for fresh blood circulation to the affected area.

Agni: Patrangadi yoga causes deepana (katu, kashaya rasa,ushna snd teekshna guna) and pachana (tiktarasa and ushna guna). This process increases the jataragni and dhatvagni and helps in bringing the vitiated doshas to normal form.

Because of grahi, stambhana (kashaya rasa) action does act as drava shoshana, decreasing the sraava, thus helping in samprapti vighatana of sleshmala yonivyapad.

Discussion on correlation between shleshmala yonivyapat and trichomonas vaginalis:

Lakshanas of Shleshmala yoni vyapat are picchila, sheeta, pandu varna yoni srava, kandu and alpa vedana which closely resemble with,

Trichomonas vaginalis- shows clinical features as greenish yellow frothy vaginal discharge, irritation, itching and dysuria.

According to contemporary science douching is bad for health because it disturbs normal chemical and microbial 
balance of the vagina, possibly leading to bacterial vaginosis or other bacterial infections and it may also lead to infertility. But in our classics many local treatments are mentioned in shleshmala yonivyapat among them yoni prakshalana is one.

\section{CONCLUSION}

Due to the kaphaprakopaka ahara and vihara, there will be vitiation of kapha dosha, which in turn vitiates the yoni and manifests shleshmala yonivyapat, characterized by picchila, sheeta, pandu varna yonisrava, kandu and alpavedana. This can be correlated to trichomonas vaginalis.

In the present study, an attempt was made to evaluate the efficacy of patrangadi yoga which is anubhoota yoga in shleshmala yonivyapat.

Based on the present study, it was found that patrangadi yoga, these combination of drugs have got kashaya and katu rasa pradhanyata, laghu, ruksha, deepana, pachana, grahi, sthambana, lekhana, kandughna and krimighna guna, ushna veerya, sugandhi dravya.

Patrangadi kashaya yoniprakshalana, due to its laghu and ruksha guna enable to act effectively against the kapha prakopa lakshana and it also has shothaghna and vranaghna properties which help to rectify the inflammation of vagina. Patrangadi kashaya yoniprakshalana and patrangadi churna orally with ushnodaka gives added benefit in the management of shleshmala yonivyapat and no adverse effects are seen during the treatment.

From the current study we obtained the following result with the help of required assessment criteria:

Effect on picchila shwetasrava-60.59\%

Effect on dourgandya-100\%

Effect on kandu $-60.59 \%$.

Effect on alpavedana is $69.07 \%$.

The effect of therapies on individual objective parameters:

Effect of profuse thick creamy discharge- $63.16 \%$.
Effect of Red and swollen vulva with evidence of pruritis like scratch marks$55.94 \%$.

Effect of Wet mount showing trichomonas vaginalis positive- $79.38 \%$.

Based on the results we can say that Patrangadi yoga is effective in treating the shleshmala yonivyapat.

\section{Acknowledgement: None}

\section{Conflict of Interest: None}

\section{Source of Funding: None}

\section{Ethical Approval: Approved}

\section{REFERENCES}

1. Agnivesha Charaka Samhita with Ayurvaeda Dipika commentary of chakrapanidatta;revised by Charaka and Drdhabala, Edited by Yadavji Trikamji, Chikitsa sthana 30/7, Published by Krishnadas Academy, Varanasi,Edition 2000, pg:634

2. Sushruta, Sushruta Samhita, Ayurveda Tatva Sandipika, Hindi commentary, Edited by Kaviraja Ambikadutta Shastri, Uttara tantra 38/17, Published by Chaukambha Sanskrit Sansthan, Varanasi, Reprint, 2018, Pg:207

3. Vagbhata, Astanga Hrudayam, Sarvnanga Sundara Commentary of arunadatta, Ayurveda Rasayana Commentary of Hemadri, Edited by Bhishagacharya Hari Sadashiva Shastri Paradakara Vaidya, Uttara tantra 33/44,45, Published by Choukamba Orientalia , Varanasi. Reprint 2014 page no -896

4. Sushruta, Sushruta Samhita, Ayurveda Tatva Sandipika, Hindi commentary, Edited by Kaviraja Ambikadutta Shastri,Sutra sthana 21/18,19, Published by Chaukambha Sanskrit Sansthan, Varanasi, Reprint, 2018, Pg: 117,118

5. Agnivesha Charaka Samhita with Ayurvaeda Dipika commentary of chakrapanidatta;revised by Charaka and Drdhabala, Edited by Yadavji Trikamji, Chikitsa sthana 28/15,16,17,18 Published by Krishnadas Academy, Varanasi,Edition 2000, pg:617 
6. Agnivesha Charaka Samhita with Ayurvaeda Dipika commentary of chakrapanidatta;revised by Charaka and Drdhabala, Edited by Yadavji Trikamji, Chikitsa sthana 30/13,14 Published by Krishnadas Academy, Varanasi,Edition 2000, pg:635

7. Agnivesha Charaka Samhita with Ayurvaeda Dipika commentary of chakrapanidatta;revised by Charaka and Drdhabala, Edited by Yadavji Trikamji, Chikitsa sthana 30/13 Published by Krishnadas Academy, Varanasi,Edition 2000, pg:635

8. Sushruta, Sushruta Samhita, Ayurveda Tatva Sandipika, Hindi commentary, Edited by Kaviraja Ambikadutta Shastri, Uttara tantra 38/17, Published by Chaukambha Sanskrit Sansthan, Varanasi, Reprint, 2018, $\mathrm{Pg}: 207$

9. Vagbhata, Astanga Sangraha, Hindi Commentary By Kaviraj Atrideva Gupta, Forword by Rajvaidya Pandit Sri Nandakishor Sharma Bhishagacharya, Uttara tantra 38/46, Published by
Krishnadas Academy,Varanasi,2005 page no -330

10. Agnivesha Charaka Samhita with Ayurvaeda Dipika commentary of chakrapanidatta;revised by Charaka and Drdhabala, Edited by Yadavji Trikamji, Chikitsa sthana 30/13,14 Published by Krishnadas Academy, Varanasi,Edition 2000, pg:635

11. Madhavakara, Madhavanidana with Madhukosha Sanskrit commentary by Vijayarakshita and Srikanthadatta, Edited with 'Vimala'-'Madhudhara' hindi commentary by Dr. Brahmanand Tripathi vol.2, 62/10, Published by Chaukhamba Surabharati Prakashan, Varanasi, 2002,Pg no:489

How to cite this article: Sindagi S, Sajjan S, Halagatti A. A clinical study on sleshmala yonivyapad through anubhoota yoga the 'patrangadi yoga'. Int J Health Sci Res. 2021; 11(10): 109-117. DOI: https://doi.org/10. 52403/ijhsr.20211014 